\title{
内蒙古呼伦湖表层沉积物的 矿物组成和沉积速率・
}

吉磊夏威佩贡亮王苏民

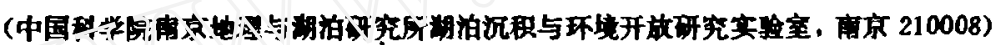

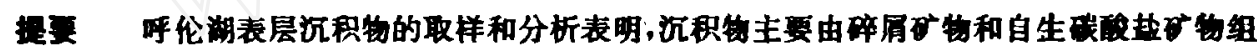

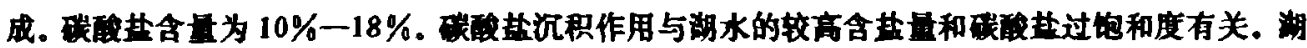
泊中心 HL8 号柱样的 ${ }^{210} \mathrm{~Pb}$ 河定结果是, $10 \mathrm{~cm}$ 以上平均沉积速事 $0.25 \mathrm{~cm} / \mathrm{s}, 10-12 \mathrm{~cm}$ 为 0.05 $\mathrm{cm} / \mathrm{a} .60$ 年代开始随湖泊水位上胀沉积物输入量迅速加大。

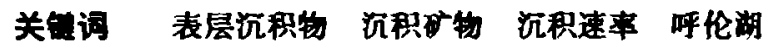

呼伦湖,也称达势湖、呼伦池, 位于内蒙古呼伦贝尔草原西部。湖泊面积 $2379 \mathrm{~km}^{2}$, 平均 水深 $5.7 \mathrm{~m}$, 最大水深 $8 \mathrm{~m}$ 左右 ${ }^{[1]}$, 是我国第五大湖, 也是我国纬度最高的大湖 $\left(117^{\circ} 00^{\circ} 10^{\circ} \mathrm{E}\right.$ $\left.-117^{\circ} 41^{\prime} 40^{\prime} \mathrm{E}, 48^{\circ} 30^{\prime} 40^{\prime} \mathrm{N}-49^{\circ} 20^{\prime} 40^{\prime} \mathrm{N}\right)$ 。呼伦湖不仅是我国北方重要的淡水渔业生产基 地，也是著名的迸暑旅游胜地。然而由于位置侮僻、交通不便等原因,过去对呼伦湖的科学 调查和研究较为葆弱。1991 年夏,我们对呼伦旍进行了科学考察,对湖泊表层沉积物进行采 样分析，研究了沉积物的化学成分、矿物成分和近代沉积速率。

\section{1 自然地理概况}

呼伦湖处于中高纬度过渡区，風中温带(接近北温带)半于旱大陆性气垁。在湖区的扎责 诺尔,年均气温 $-1.3 \mathrm{C}$,年均阵水量 $319 \mathrm{~mm}$,年均日照 $2840 \mathrm{~h}$,年均蒸发量 $1406 \mathrm{~mm}^{[1]}$ 。

湖水的补给除来自降水和地下水外，注入湖泊的河流主要有两条，即从湖西南流入的克

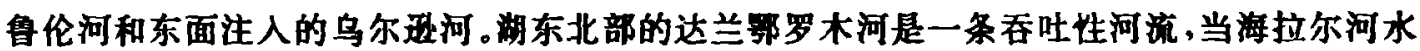
高于呼伦湖时，河水注入呼伦湖，反之呼伦湖水原达兰㔀罗木河流向新尔古纳河。

湖水的含盐量消湖泊水量变化而改变。1962 年湖水位 $548.28 \mathrm{~m}$,含盐量 $777 \mathrm{mg} / \mathrm{L}$ ； 1981 年湖水位 $543.32 \mathrm{~m}$ ，含盐量提高到 $1261 \mathrm{mg} / \mathrm{L} ; \mathrm{pH}$ 值 8.85 , 政度 $13.76 \mathrm{me} / \mathrm{L}$ ，总硬度 17. 79,水型 $\mathrm{C}_{\mathrm{N}}^{\mathrm{Na}}$; 据 1985 年的资料，含盐量 $1055 \mathrm{mg} / \mathrm{L}, \mathrm{pH}$ 值 8.8 , 践度 $10.03 \mathrm{me} / \mathrm{L}$, 总硬度 $15.67^{[1]}$ 。

1991 年我们对呼伦湖的湖水重新进行了水化学分析,结果表明湖水平诗含盐量是 1155

- 国家自然科学基金妾员会资助项目 (49172119)。

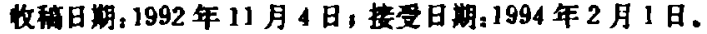


$\mathrm{mg} / \mathrm{L}, \mathrm{pH}$ 值 8.71 , 㼛度 $11.03 \mathrm{me} / \mathrm{L}$, 总硬度 14.89 , 水型仍为 $\mathrm{C}_{\mathrm{I}}^{\mathrm{N}}$ 。

\section{2 表层沉积物的矿物和化学成分}

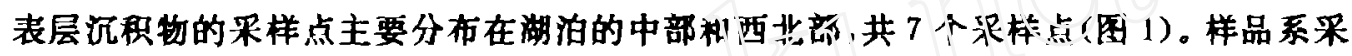
用重力采样器获取，取表层 $2 \mathrm{~cm}$ 样品供研究行。

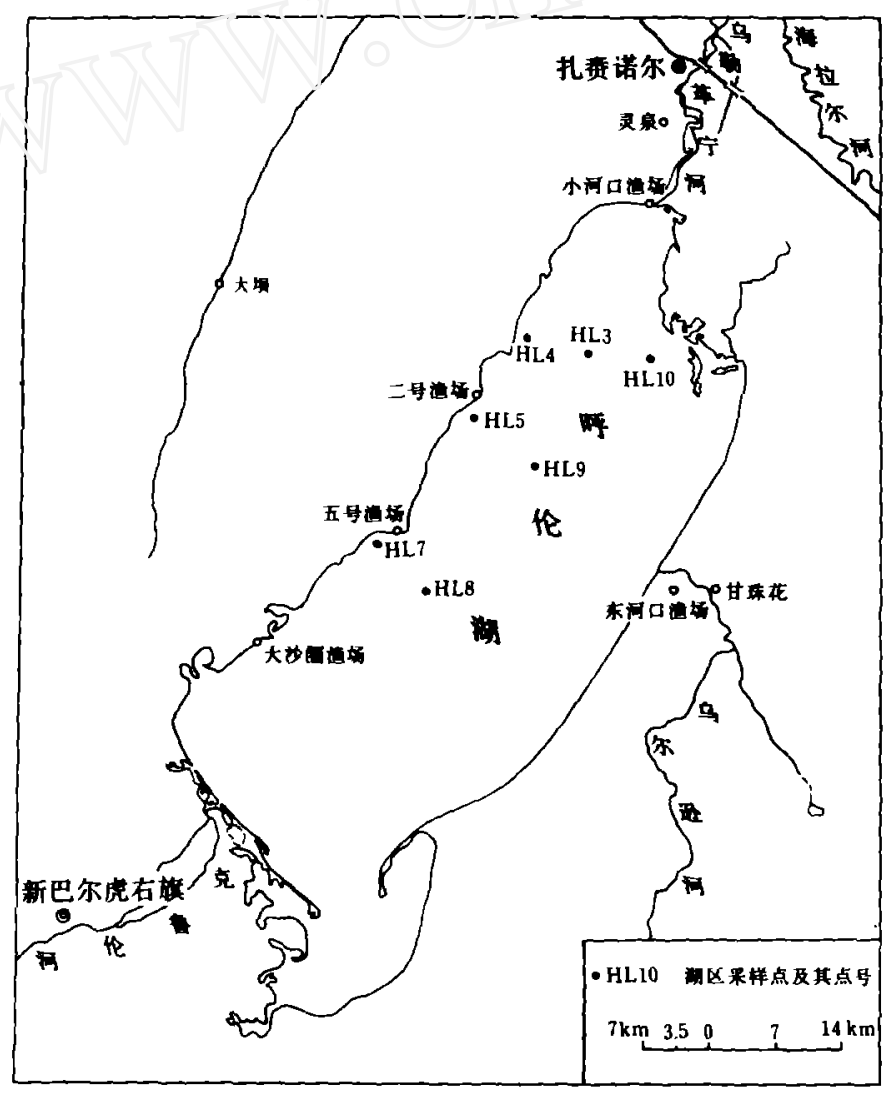

㲚 1 呼伦湖及采样点位团

Fig. 1 Hulun Lake and the sampling tocation

呼伦湖湖底表层沉积物分布不均一,西北部柆度较细,以枌砂质粘土为主,而南部和东 部则主要分布砂质沉积。这是由于克苗伦河和乌尔逊河的入湖口分别在湖泊的南何和东

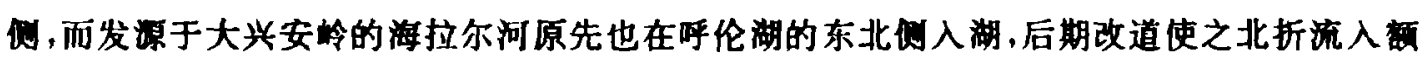

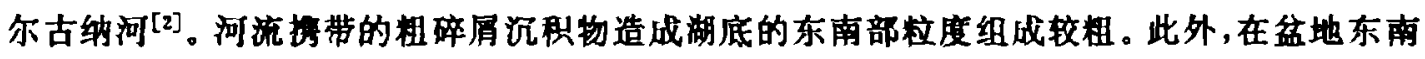
乌尔逊河河道、阶地和海拉尔河故道附近分布了大范用的砂质沉积物，在风力作用下可以将 碎屏物投运至湖滨和湖内再沉积，因此，湖泊表层沉积物的相碎局分布也可能与风力近距禹 搬运作用有关。 
上述 7 个采样点除 HL9 外，均分布在细粒沉积物区。对沉积物样品采用光透式粒度仪 和音波振动式第分仪进行粒度分析，其结果除 HL 9 外,其余样品的柆度中值为 7.0-9.2 (0.007-0.002 mm),均为粘土级一极细枌级组分 (表 1). 我国一些较深的大湖通常沉积 物粒度较细，如云南洱海、滇池和抚仙湖中，>89 柆级组分占湖泊面积的 $75 \%-31.6 \%$ ；而 一些深度较小的湖泊如长江中下洋五大水湖沉积物中，>89 组分只志湖泊面积的 $25 \%-65 \%[3]$ 。

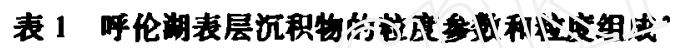

Tab. 1 Grainsize parametere arid lompouitions of gusticial sediments in Hulun Lake

\begin{tabular}{|c|c|c|c|c|c|c|c|c|c|c|}
\hline \multirow{2}{*}{ 米样点 } & \multirow{2}{*}{ 水湴(m) } & \multirow{2}{*}{$\begin{array}{l}M S(=) \\
\text { (中值) }\end{array}$} & \multirow{2}{*}{ 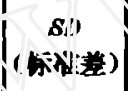 } & \multirow{2}{*}{$\begin{array}{c}S_{+} \\
\text {他度) }\end{array}$} & \multirow{2}{*}{ 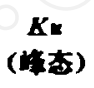 } & \multirow{2}{*}{$\begin{array}{c}\boldsymbol{S} 0 \\
\text { (分选度) }\end{array}$} & \multicolumn{4}{|c|}{ 柆度 组 成 } \\
\hline & & & & & & & $<-1 \Phi$ & $-1-4 \Phi$ & $4-8 \Phi$ & $>8 \varphi$ \\
\hline HL3 & 8.2 & 8.380 & 2.055 & -1.159 & 3.347 & 2.790 & 0 & 5.85 & 25.1 & 69.14 \\
\hline HLA & 6.9 & 8. 677 & 1.729 & -1.385 & 4. 349 & 2.512 & 0 & 1.69 & 22.64 & 75. 67 \\
\hline HL5 & 6.8 & 8. 556 & 1.855 & -1.208 & 3. 492 & 2.630 & 0 & 1. 42 & 25. 10 & 73. 48 \\
\hline HL7 & 6. 2 & 6.812 & 2. 493 & -0.040 & 1.554 & 5.823 & 0 & 18.46 & 43.09 & 38.46 \\
\hline HL8 & 7.0 & 7.001 & 2. 789 & -0.454 & 1.804 & 5.674 & 0 & 20.44 & 33.48 & 46.08 \\
\hline HL9 & 7. 2 & 1.896 & 2. 889 & 1.059 & 3. 334 & 3.457 & 13. 20 & 68.21 & 12.21 & 6.37 \\
\hline HL 10 & 6.8 & 7.716 & 2. 281 & -0.655 & 2. 304 & 3.819 & 0 & 7.24 & 38.91 & 53.85 \\
\hline
\end{tabular}

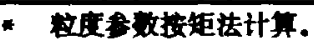

沉积物样品经镜下篮定主要矿物成分是粘土物和方解石, 含少量枌砂和砂等粒。后者 主要是石英、钾长石、斜长石、云母和少量重矿物及岩屃。方解石属自生矿物,呈微晶或微晶 集合体, 晶柆粒径为 $0.002-0.01 \mathrm{~mm}$, 含量 5\%-20\%。采样点 HL 9 样品是含秒细砾沉积, 碳酸盐矿物含量较低。

对沉积物粉末样品进行了 X 射线行射分析, 用特征篮定峰强度因子法 ${ }^{[4]}$ 半定量计算其 物类型及含量。结果显示,除粘土物外,主要物是石英、银长石、斜长石和方解石(表

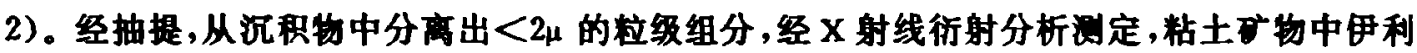
石含量最高,约占 $69 \%$,绿㳸石和蒙脱石各占约 $21 \%$ 和 $10 \%$ 。

毒 2 呼伦湖表层讯积物的矿物成分 $(\%)^{\circ}$

Tab. 2 Mineral composition of surficial sediments in Hulun Lake (\%)

\begin{tabular}{|c|c|c|c|c|c|}
\hline 来样点 & 沉积特 & 石 英 & 的长石 & 銯长石 & 方解石 \\
\hline HL3 & 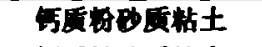 & 14 & 32 & 26 & 28 \\
\hline HL4 & 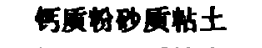 & 25 & 29 & 23 & 23 \\
\hline HL5 & 烦原初的面站土 & 31 & 19 & 27 & 23 \\
\hline HL8 & 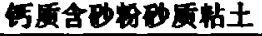 & 29 & 24 & 27 & 20 \\
\hline
\end{tabular}

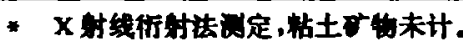

呼伦湖沉积物中方解石的形成主要与湖水的化学过程有关。据 1985 年的水化学分析资 料 ${ }^{[1]}$, 呼伦湖湖水平均含盐量 $1055 \mathrm{mg} / \mathrm{L}, \mathrm{pH}$ 值 $8.8, \mathrm{Ca}^{2+} 、 \mathrm{CO}_{3}^{2-}$ 和 $\mathrm{HCO}_{3}$ 离子浓度分别是 $24.71 \mathrm{mg} / \mathrm{L} 、 1.41 \mathrm{me} / \mathrm{L}$ 和 $8.62 \mathrm{me} / \mathrm{L}$ 。经碳酸盐饱和度计算 ${ }^{[5]}$, 湖水中碳酸钻已达到过饱 和状态,具备碳酸盐化学沉淀的基本条件。

笔者进一步对沉积物的碳酸盐含量和有机碳含量作了定量试试。碳酸盍分析采用库伦 法,结果表明，样品碳酸盐含量为 $10.1 \%-17.6 \%$ 。个别样品如 HL 10 碳酸盐含量不到 $2 \%$ 
（表 3),这是由于 HL10 处于海拉尔河三角洲的前缭,大量陆源碎局的输入使碳酸盐矿物被 稀释，造成碳酸盐含量的低值。

表 3 呼伦湖表层沉积物的 $\mathrm{CaCO}$, 和 $\mathrm{C}_{\text {和 }}$ 含量 (\%重量)

Tab. 3 CaCO, and $\mathrm{C}_{\text {are }}$ contents of surficial sediments in Hulun Lake

\begin{tabular}{|c|c|c|c|}
\hline 来样 点 & 沿积 物 & Cacos & Enn \\
\hline HL3 & 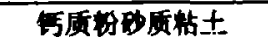 & & 5. 20 \\
\hline HLA & 饭质略质站土 & 14.24 & 3. 91 \\
\hline HL5 & 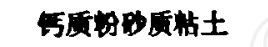 & i4. 42 & 4. 33 \\
\hline HL7 & 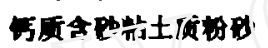 & 10.14 & 2.76 \\
\hline HL8 & 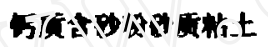 & 17.58 & 4. 53 \\
\hline HL9 & 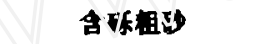 & 12.42 & 1.67 \\
\hline HL10 & 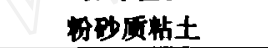 & 1.91 & 1.11 \\
\hline
\end{tabular}

有机碳分析采用氧化还原电位滴定法,测试结果(表 3)显示,有机碳含量除个别采样点 如 HL 9、HL 10 较低外, 大多数均较高, 其含量变化范围在 $1.1 \%-5.2 \%$ 之间,平均值 3 . $4 \%$ 。较高的有机碳含量说明湖泊具有较高的切始生产力。此外,湖水较深、水温较低也使 得 沉积物中的有机质难以分解。

\section{3 沉积速率}

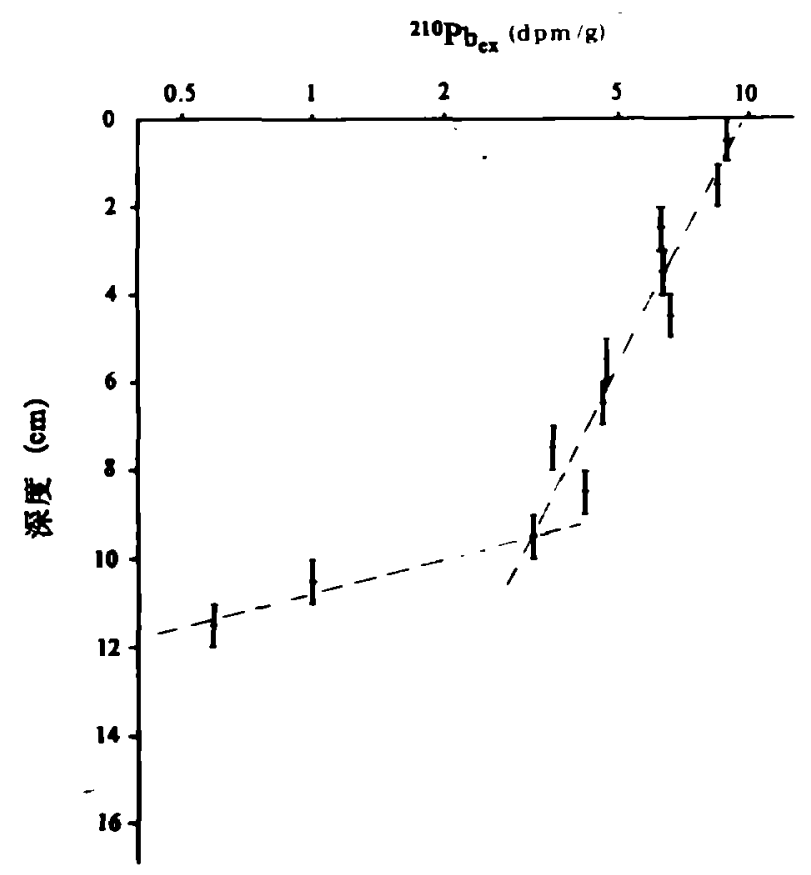

国 2 HL8 采样点柱样的过量 ${ }^{210} \mathrm{~Pb}$ 垂直分布

Fig. 2 Vertical distribution of excess ${ }^{210} \mathrm{~Pb}$ in core $\mathrm{HL} 8$
在 HL8 号采样点获取了一梁约 $20 \mathrm{~cm}$ 的柱样用于湖泊沉积物的沉 积速率。样品以 $1 \mathrm{~cm}$ 的间隔分取,称重 后娂干,求出含水量。加入 ${ }^{208} \mathrm{Po}$ 示踪剂, 用硝酸处理后再用盐酸浸取出样品中 的 ${ }^{210} \mathrm{Po}$, 使 Po 同位亲铰在银片上。由 1024 道多道分析仪与金硅面垒探测器组 成的 $\alpha$ 能㙕仪测得 ${ }^{210} \mathrm{Po}$ 和 ${ }^{208} \mathrm{Po}$ 计数, 由 ${ }^{210} \mathrm{Po}$ 含量求得样品中 ${ }^{210} \mathrm{~Pb}$ 的放射性 比度。

用 ${ }^{210} \mathrm{~Pb}$ 法的 CIC 模式计算了 HL8 号柱样的沉积物沉积速率 ${ }^{[6,7]}$ 。选择 CIC 模式的沉积环境应是沉积物来源于充分 接受了大气中 ${ }^{210} \mathrm{~Pb}$ 沉降的物源(如流域 侵蚛产物)，并且在湖水中海留时间较 短，沉积物中的 ${ }^{210} \mathrm{~Pb}$ 含量明显受物源 影响, 即沉积物的增加能同时导致相应 的 ${ }^{210} \mathrm{~Pb}$ 增加。这样才能保证沉积物一水 界面放射性比度的平街 ${ }^{[0]}$ 。 
困 2 是呼伦湖 $\mathrm{HL} 8$ 柱样的过量 ${ }^{210} \mathrm{~Pb}$ 随深度变化的分布国。经计算得出 $10 \mathrm{~cm}$ 处沉积物 年砱为公元 1959 年, $10 \mathrm{~cm}$ 以上平均沉积速率为 $0.25 \mathrm{~cm} / \mathrm{a}, 10-12$ 为 $0.05 \mathrm{~cm} / \mathrm{a}, 10 \mathrm{~cm}$ 处 存在一个显著的沉积速率变化界面。可见,60 年代开始㭔伦期沉积速事明显加大。

据水文、人文调查资料，呼伦湖在本世纪 40 年代前水位虽有波动，但湖面怒小，水位低

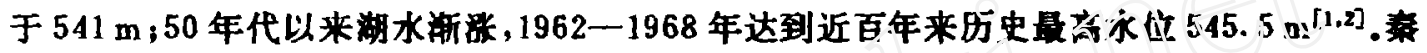

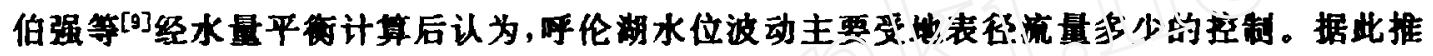

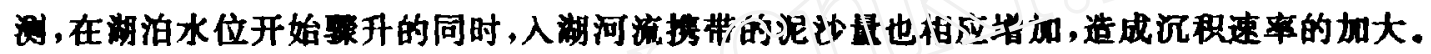

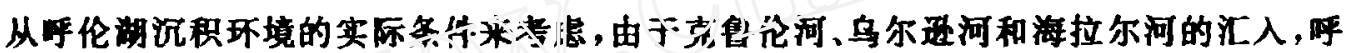

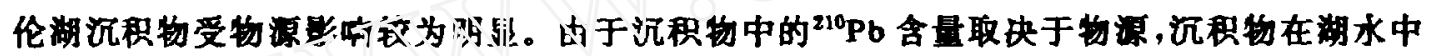
滞留时间亦较短：因此注采住点 HL8 计算其沉积速率时，用 CIC 模式与实际情况较为接近.

\section{4 结 论}

（1）呼伦湖表层沉积物的主要矿物组成包括外源组分(即石英、长石、云母和粘土物 等)和自生组分 (主要是方解石)。化学分析表明沉积物碳酸盐含量为 $5-18 \%$ 。碳酸盐沉积与湖水的较高含盐量有关。

(2) 对湖泊中心部位(HL8 采样点)柱状样进行了 ${ }^{210} \mathrm{~Pb}$ 跑试, 用 CIC 模式计算其沉积速 率, 说明 60 年代以来平均沉积速率是 $0.25 \mathrm{~cm} / \mathrm{a}$ 。

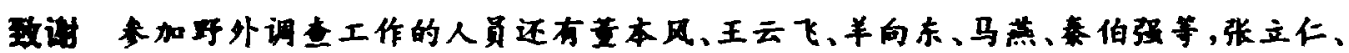

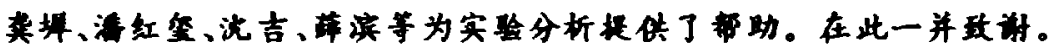

\section{考文获}

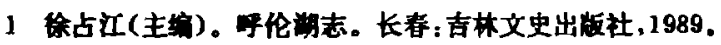

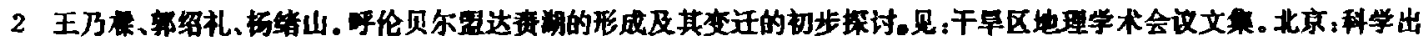
肘社, 1965:22-31.

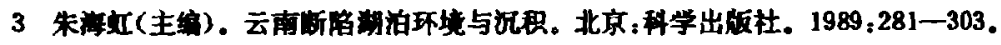

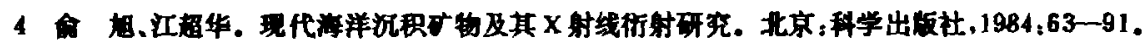

5 Kelts, K. , K. J. , Hsu. , Freshwater carbonate sedimentation. In : A. Lerman ed. , Lakea : chemistry, geology, physics. New York : Springer-Verleg, 1978 ; 295-323.

$6 \mathrm{MCCall}, \mathrm{P} . \mathrm{L}$. et al. , ${ }^{137} \mathrm{Cs}$ and ${ }^{230} \mathrm{~Pb}$ transport and geochronology in urbanized reservoirs with rapidly increasing sedimentation rates. Chem. Geol., 1984, 14:33-65.

7 Rabbins, J. A. , Geochemical geophysical applications of radiouctive lead iatopes. In: J. P. Nriago ed. , Biogeochemistry of lead. Elsevier, 1978, 285-393.

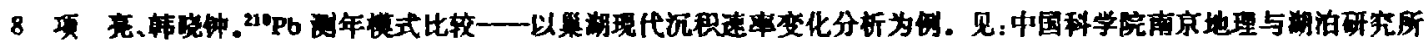
集刑, 第 9 每。北京: 科学出版杜, 1993 ; 104-112.

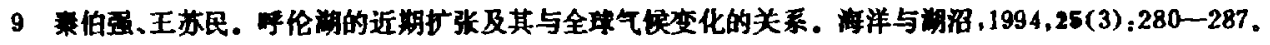




\title{
MINERAL COMPOSITION AND SEDIMENTATION RATE OF SURFICIAL SEDIMENTS IN HULUN ¿AKE, INNER MONGOLIA
}

\author{
Ji Lei Yia Weilan Kiang Liang Wang Sumin

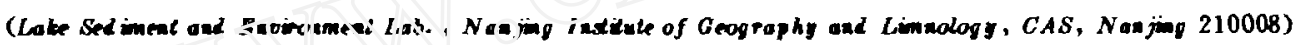

\begin{abstract}
Hulun Lake, the fifth largest lake in China, is located in the west side of Hulun Buir Prairie. It was seldom studied and understood before due to the remote border district. The observation and sampling of the modern sediment in Hulun Lake has been carried out and the mineral composition and the sedimentation rate analysed recently.

The surficial sediments of Hulun Lake are distributed unevenly, for the lake is linked to the influxes of the Herlen River, the Orxon River and the ancient Harlar River. Grainsize analysis of 7 sediment samples in the northwest demonstrates that the median size of most sample is $7.0-9.2 \varphi$, falling in the size fraction of clay-very fine silts. Mineral identification by microscope and XRD analysis for the sediment shows that the sediments are such allogenic minerals as quartz, feldspar, mica and heavy minerals and authigenic minerals, mainly calcite. Carbonate content of the sediment samples ranges from $10.1 \%$ to $17.6 \%$ indicated by chemical analysis, which is linked to higher salinity and supersaturation to carbonate of the lake water.

${ }^{210} \mathrm{~Pb}$ dating was tested for a short core in the central part (site HL8) of the lake and the sedimentation rate was calculated using CIC model. The average sẹtimentation rate is 0.25 $\mathrm{cm} / \mathrm{a}$ above $10 \mathrm{~cm}$-depth of the core and $0.05 \mathrm{~cm} / \mathrm{a}$ in $10-12 \mathrm{~cm}$, implying higher sedimentation rate since 1959 A. D. Based on the hydrologyical data, the lake level rose gradually begining from the 1950 s and up to its historical highest in the 1960 s. It is inferred that the influx sediment amount increased as the lake level rose.
\end{abstract}

Key Words Surficial sediment, sedimentary mineral, sedimentation rate, Hulun Lake 